\title{
Karakteristik Fisik Dan Mekanik Tanah Residual Balikpapan Utara Akibat Pengaruh Variasi Kadar Air
}

\author{
Mohammad Muntaha1, Lintang Caraka2, dan Andika A.I. Saputra2 \\ ${ }^{1}$ Jurusan Teknik Sipil, Institut Teknologi Sepuluh Nopember (ITS) Surabaya \\ ${ }^{2}$ Jurusan Teknik Sipil dan Perencanaan, Institut Teknologi Kalimantan (ITK) Balikpapan \\ mohamadmuntaha@yahoo.com
}

\begin{abstract}
Abstrak
Kota Balikpapan terletak di dekat garis khaturistiwa yang beriklim tropis mengakibatkan peristiwa alam berupa pembasahan pada musim penghujan dan pengeringan saat musim kemarau yang berlangsung sepanjang tahun. Proses pembasahan dan pengeringan akan mempengaruhi sifat fisik dan mekanik dari tanah, karena perubahan kadar air dapat mengakibatkan perubahan volume tanah. Sampel pengujian tanah residual di ambil dari 3 lereng tanah residual yaitu ITK Balikpapan, PLTU Kariangau Balikpapan, dan PJI Balikpapan Utara; dengan menitikberatkan pengaruh variasi kadar air (pembasahan dan pengeringan) terhadap sifat fisik dan sifat mekanik tanah, pada tanah yang diambil pada kedalaman -0.5 m sampai dengan -1.5 m. Pengujian sifat fisik meliputi berat jenis tanah $(\gamma \mathrm{t})$, berat jenis kering tanah ( $\gamma \mathrm{d})$, kadar air (wc), derajat kejenuhan (Sr), porositas (n), angka pori (e), Spesific Gravity (Gs) dan batas Atterberg (LL, PL, PI). Pengujian sifat mekanik yaitu kohesi (c) dan sudut geser dalam $(\varphi)$. Proses pembasahan dilakukan dengan cara menambahkan kadar air dari kondisi awal (wi) sampai kondisi kadar air jenuh (wsat), variasi penambahan kadar air sebesar 25\%, 50\%, 75\%, dan 100\% dari selisih kondisi kadar air. Sedangkan proses pengeringan dilakukan dengan cara mengurangi kadar air dari kondisi awal (wi) sampai kondisi kadar air kering (wdry), variasi pengurangan kadar air sebesar 25\%, 50\%, 75\%, dan 100\% dari selisih kadar air. Hasil pengujian menunjukkan terjadinya variasi perubahan sifat fisik dan mekanik yang cukup besar selama proses pembasahan dan pengeringan. Pada kedalaman $0,5 \mathrm{~m}$ tanah residual ITK, saat pembasahan mengalami penurunan kohesi 30,24\%, dan angka pori naik sebesar 42,25\%; tanah residual PLTU mengalami penurunan kohesi tanah 15,29\%, dan angka pori naik sebesar 35,38\%; tanah residual PJI mengalami penurunan kohesi tanah $31,59 \%$, dan angka pori naik sebesar 31,79\%. Selama proses pengeringan dari kondisi inisial kekondisi pengeringan $100 \%$, tanah residual ITK mengalami peningkatan kohesi tanah 34,09\%, dan angka pori turun sebesar 55,30\%; tanah residual PLTU mengalami peningkatan kohesi tanah 26,01\%, dan angka pori turun sebesar 53,40\%; dan tanah residual PJI mengalami penigkatan kohesi tanah 29,14\%, dan angka pori turun sebesar $53,87 \%$.

Kata kunci : variasi kadar air, pembasahan, pengeringan, sifat fisik, sifat mekanik, tanah permukaan, lereng, faktor keamanan, Karang Joang - Balikpapan Utara
\end{abstract}

\section{PENDAhuluan}

Kota Balikpapan terletak di dekat garis khaturistiwa yang beriklim tropis sehingga mempunyai dua musim, yaitu: musim penghujan dan musim kemarau. Musim kemarau biasa terjadi antara bulan Mei sampai dengan Oktober, sedangkan musim penghujan terjadi antara bulan November sampai dengan bulan April. Bappaeda Kota Balikpapan tahun 2014 mencatat curah hujan rata-rata tertinggi adalah $705 \mathrm{~mm}$ dan rata-rata terendah tercatat $71 \mathrm{~mm}$. Pergantian musim hujan ke musim kemarau atau sebaliknya dapat mengakibatkan terjadinya proses pembasahan dan pengeringan secara berulang-ulang. Hal tersebut dapat mempengaruhi karakteristik fisik dan mekanik tanah di Balikpapan yang diakibatkan oleh variasi kadar air. Maekawa dan Miyakita (1991) menyimpulkan bahwa jumlah siklus pengeringan dan pembasahan berulang akan mengurangi kekuatan geser tanah, sampai pada jumlah siklus tertentu. Muntaha (2012) mendapatkan penurunan kekuatan sebesar $12 \%$ pada tanah residual akibat siklus pembasahan dan pengeringan. Pengujian yang di lakukan menitikberatkan pengaruh variasi kadar air, dengan melakukan proses pembasahan dan pengeringan pada tanah resdiual permukaan [1]. Sampel pengujian tanah residual di ambil dari 3 lereng tanah residual yaitu ITK Balikpapan, PLTU Kariangau Balikpapan, dan PJI Balikpapan Utara, yang diambil pada kedalaman -0,5 m sampai dengan -1,5 m. Pengujian sifat fisik meliputi berat jenis tanah $\left(\gamma_{\mathrm{t}}\right)$, berat jenis kering tanah $\left(\gamma_{\mathrm{d}}\right)$, kadar air $\left(\mathrm{w}_{\mathrm{c}}\right)$, derajat kejenuhan $\left(\mathrm{S}_{\mathrm{r}}\right)$, porositas $(\mathrm{n})$, angka pori $(\mathrm{e})$, Spesific Gravity $\left(\mathrm{G}_{\mathrm{s}}\right)$ dan batas Atterberg $(\mathrm{LL}$, PL, PI). Pengujian sifat mekanik yaitu kohesi (c) dan sudut geser dalam $(\varphi)$. Hasil pengujian dibuat hubungan antar karakteristik fisik, dan mekanik tanah akibat pengaruh variasi kadar air terhadap stabilitas lereng.

\section{TINJAUAN PUSTAKA}

Karakteristik statik tanah terdiri atas karakteristik fisik dan mekanik. Karakteristik fisik meliputi kadar air, berat volume tanah, berat spesifik dan batas batas Atterberg, Karakteristik mekanik meliputi kohesi dan sudut geser dalam.

\subsection{Sifat Fisik Tanah}

Sifat fisik tanah yaitu sifat yang berhubungan dengan elemen penyusunan massa tanah yang ada. Dalam keadaan tidak jenuh, tanah terdiri dari 3 (tiga) bagian yaitu butiran padat (solid), bagian air (water) dan bagian udara (air). Keberadaan 
materi air dan udara biasanya menempati pada ruangan antara butiran/pori pada massa tanah tersebut. Ilustrasi untuk memahami susunan elemen pada massa tanah dapat diasumsikan seperti gambar 1 berikut [2]. Beberapa nilai parameter fisik tanah seperti terlihat pada Tabel 1.
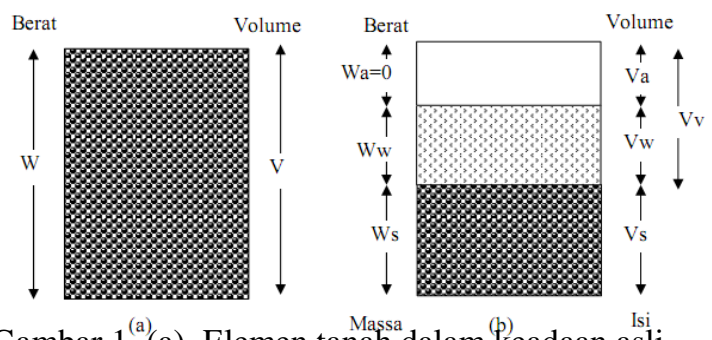

Gambar 1.(a). Elemen tanah dalam keadaan asli

\section{(b). Tiga fase elemen tanah}

Gambar 1(a) memperlihatkan elemen tanah yang mempunyai volume V dan W, sedangkan Gambar 1(b) memperlihatkan hubungan berat dan volume tanah dalam tiga fase yang dipisahkan (butiran padat, air dan udara). Berat udara dianggap sama dengan nol. Hubungan volume yang umum dipakai untuk suatu elemen tanah adalah sebagai berikut.

1. Angka pori $(\mathrm{e})$ adalah perbandingan volume rongga $\left(\mathrm{V}_{\mathrm{v}}\right)$ dengan volume butiran $\left(\mathrm{V}_{\mathrm{s}}\right)$, yang dinyatakan dalam bentuk desimal.

2. Porositas $(n)$ adalah perbandingan antara volume rongga $\left(\mathrm{V}_{\mathrm{v}}\right)$ dengan dengan volume total $\left(\mathrm{V}_{\mathrm{t}}\right)$, dinyatakan dalam desimal atau prosen tetapi dalam desimal lebih diutamakan.

3. Kadar air $\left(\mathrm{W}_{\mathrm{c}}\right)$ adalah perbandingan antara berat air $\left(\mathrm{W}_{\mathrm{w}}\right)$ dengan berat butiran $\left(\mathrm{W}_{\mathrm{s}}\right)$ dalam tanah tersbut, dinyatakan dalam prosen.

4. Berat volume tanah $(\gamma)$ adalah perbandingan antara berat tanah total $\left(\mathrm{W}_{\mathrm{t}}\right)$ dengan volume tanah total $\left(\mathrm{V}_{\mathrm{t}}\right)$.

5. Berat volume kering $\left(\gamma_{d}\right)$ adalah perbandingan antara berat butiran $\left(\mathrm{W}_{\mathrm{s}}\right)$ dengan volume tanah total $\left(\mathrm{V}_{\mathrm{t}}\right)$.

6. Berat volume butiran padat $\left(\gamma_{\mathrm{s}}\right)$ adalah perbandingan antara berat butiran padat $\left(\mathrm{W}_{\mathrm{s}}\right)$ dengan volume butiran padat $\left(\mathrm{V}_{\mathrm{s}}\right)$.

7. Derajat kejenuhan $\left(\mathrm{S}_{\mathrm{r}}\right)$ adalah perbandingan antara volume air $\left(\mathrm{V}_{\mathrm{w}}\right)$ dengan volume rongga pori $\left(\mathrm{V}_{\mathrm{v}}\right)$ yang dinyatakan dalam prosen. Apabila jarak dari derajat kejenuhan dinyatakan dalam 0\% - 100\%, maka 0\% (tanah tersebut kering) dan $100 \%$ (tanah tersebut jenuh).

8. Specific Gravity $\left(\mathrm{G}_{\mathrm{s}}\right)$ perbandingan antara berat volume butiran padat $\left(\gamma_{\mathrm{s}}\right)$ dengan berat volume air $\left(\mathrm{V}_{\mathrm{w}}\right)$.

Tabel 1. Nilai Angka Pori, Kadar Air, dan Berat Volume Kering untuk Beberapa Tipe Tanah.

\begin{tabular}{|l|c|c|c|}
\hline \multicolumn{1}{|c|}{ Tipe Tanah } & $\begin{array}{c}\text { Angka } \\
\text { Pori } \\
\text { (e) }\end{array}$ & $\begin{array}{c}\text { Kadar air dalam } \\
\text { keadam jenuh } \\
\text { (\%) }\end{array}$ & $\begin{array}{c}\text { Berat vohme } \\
\text { kering } \\
(\mathbf{k N / m})^{3}\end{array}$ \\
\hline $\begin{array}{l}\text { Pasir lepas dengan butiran } \\
\text { seragam (loose uniform sand) }\end{array}$ & 0.8 & 30 & 14.5 \\
\hline $\begin{array}{l}\text { Pasir padat dengan butiran } \\
\text { seragam (dense unjform sand) }\end{array}$ & 0.45 & 16 & 18 \\
\hline $\begin{array}{l}\text { Pasir berlanau yang lepas } \\
\text { dengan butiran bersudut (loose } \\
\text { angulargrained silty sand) }\end{array}$ & 0.65 & 25 & 16 \\
\hline $\begin{array}{l}\text { Pasir berlanau yang padat dengan } \\
\text { butiran bersudut (dense } \\
\text { angulargrained silty sand) }\end{array}$ & 0.4 & 15 & 19 \\
\hline Lemipung kaku (stiff clay) & 0.6 & 21 & 17 \\
\hline Lemipung lembek (soff clay) & $0,9-1,4$ & $30-50$ & $11,5-14,5$ \\
\hline Tanah (loess) & 0.9 & 25 & 13.5 \\
\hline $\begin{array}{l}\text { Lemipung organik lembek (soft } \\
\text { organik clay) }\end{array}$ & $2,5-3,2$ & $90-120$ & $6-8$ \\
\hline Glacial till & 0.3 & 10 & 21 \\
\hline
\end{tabular}

(Sumber : Braja M. Das 1988)

\subsection{Sifat Mekanis}

Sifat mekanis tanah merupakan sifat perilaku dari struktur massa tanah pada dikenai suatu gaya atau tekanan yang dijelaskan secara teknis mekanis. Parameter kekuatan tanah tersebut terdiri dari atas:

- Kohesi $\left(\mathrm{C}_{\mathrm{u}}\right)$, yaitu gaya tarik antara butiran tanah yang tergantung pada jenis tanah dan kondisi kerapatan butir.

- Bagian butiran yang bersifat gesekan tergantung pada tekanan efektif bidang geser terhadap sudut geser dalam ( $)$ yang terbentuk.

- Modulus elastisitas merupakan perbandingan antara tegangan yang terjadi terhadap regangan. Nilai ini bisa didapatkan dari Triaxial Test, secara empiris dapat ditentukan dari jenis tanah dan data sondir.

2.3. Pembasahan dan Pengeringan

Proses pengeringan (drying) adalah suatu kondisi di mana kadar air di dalam suatu pori-pori tanah mengalami penurunan, sebaliknya pada proses pembasahan (wetting) adalah suatu kondisi di mana terjadi peningkatan kadar air di dalam pori-pori suatu massa tanah. Gambar 2. menunjukkan adanya hubungan antara nilai tegangan air pori negatif (suction) dan kadar air pada suatu tanah, yang membentuk suatu pola hysteresis dan merupakan bentuk khas dari kurva pengeringan dan pembasahan 
(drying-wetting curve) suatu tanah. Dimana grafik kurva pengeringan terletak di atas kurva pembasahan, dan bentuk kurva ini mirip dengan grafik hubungan antara perubahan angka pori dengan tegangan pada proses konsolidasi. Pada saat tanah dibebani berupa pengeringan, maka tegangan air pori negatif akan meningkat dengan semakin berkurangnya kadar air sampai tanah benar-benar kering. Bila tanah kering ini dibasahi kembali, akan terjadi penurunan tegangan air pori negatif dengan bertambahnya kadar air tanah. Namun kurvanya tidak berimpit, melainkan berada di bawah, hal ini terjadi karena, tanah bukan material yang bersifat elastis. Dari gambar ini dapat disimpulkan bahwa proses pengeringan akan menyebabkan meningkatnya tegangan air pori negatif, dan sebaliknya, proses pembasahan dapat menyebabkan mengecilnya tegangan air pori negatif.

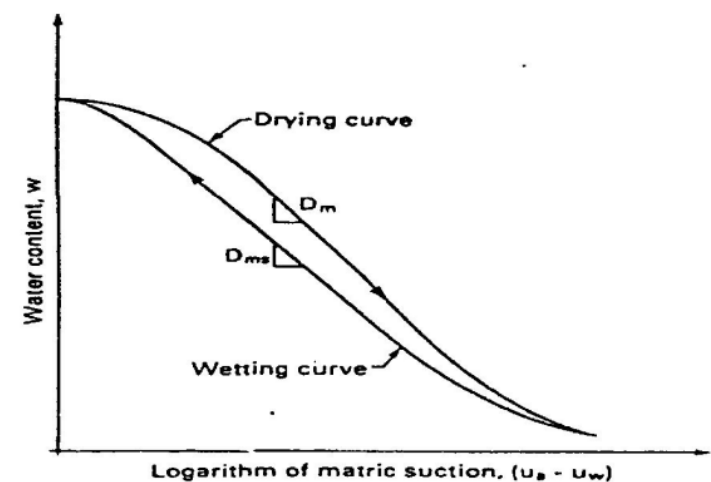

Gambar 2. Bentuk khas kurva pengeringan dan pembasahan [3]

\section{METODE PENELITIAN}

Penelitian ini berupa penelitian sifat fisik dan sifat mekanik tanah permukaan lereng tanah residual pada kedalaman -0.5 m sampai dengan -1.5 m. Pengambilan sampel dilakukan di 3 tempat yaitu Kampus ITK Balikpapan, lokasi pembangunan PLTU Kaltim Kariangau, dan lokasi Perumahan Joang Indah (PJI)-Balikpapan Utara. Penelitian dilakukan untuk mengetahui pengaruh pengeringan dan pembasahan terhadap karakteristik fisik, dan mekanik tanah residual ketiga lokasi, detail pelaksanaan penelitian sebagaimana terlihat bagan alir penelitian pada Gambar 3.

\subsection{Proses Pembahasan dan Pengeringan}

Proses pengeringan (drying) dan pembasahan (wetting) dilakukan secara bertahap berdasarkan persentase pengurangan dan penambahan kadar air. Pengkondisian pengurangan dan penambahan air ditentukan dari fungsi selisih antara kadar air jenuh $\left(\mathrm{w}_{\mathrm{sat}}\right)$ dengan kadar air awal $\left(\mathrm{w}_{\mathrm{i}}\right)$ atau $\mathrm{w}_{\mathrm{sat}}-\mathrm{w}_{\mathrm{i}}$. Pada proses pengeringan, benda uji dengan kondisi awal (initial condition) dijenuhkan hingga mencapai kadar air 100\%. Sedangkan pada proses pembasahan, benda uji dengan kondisi inisial dijenuhkan secara bertahap dengan penambahan air hingga mencapai $100 \%$.

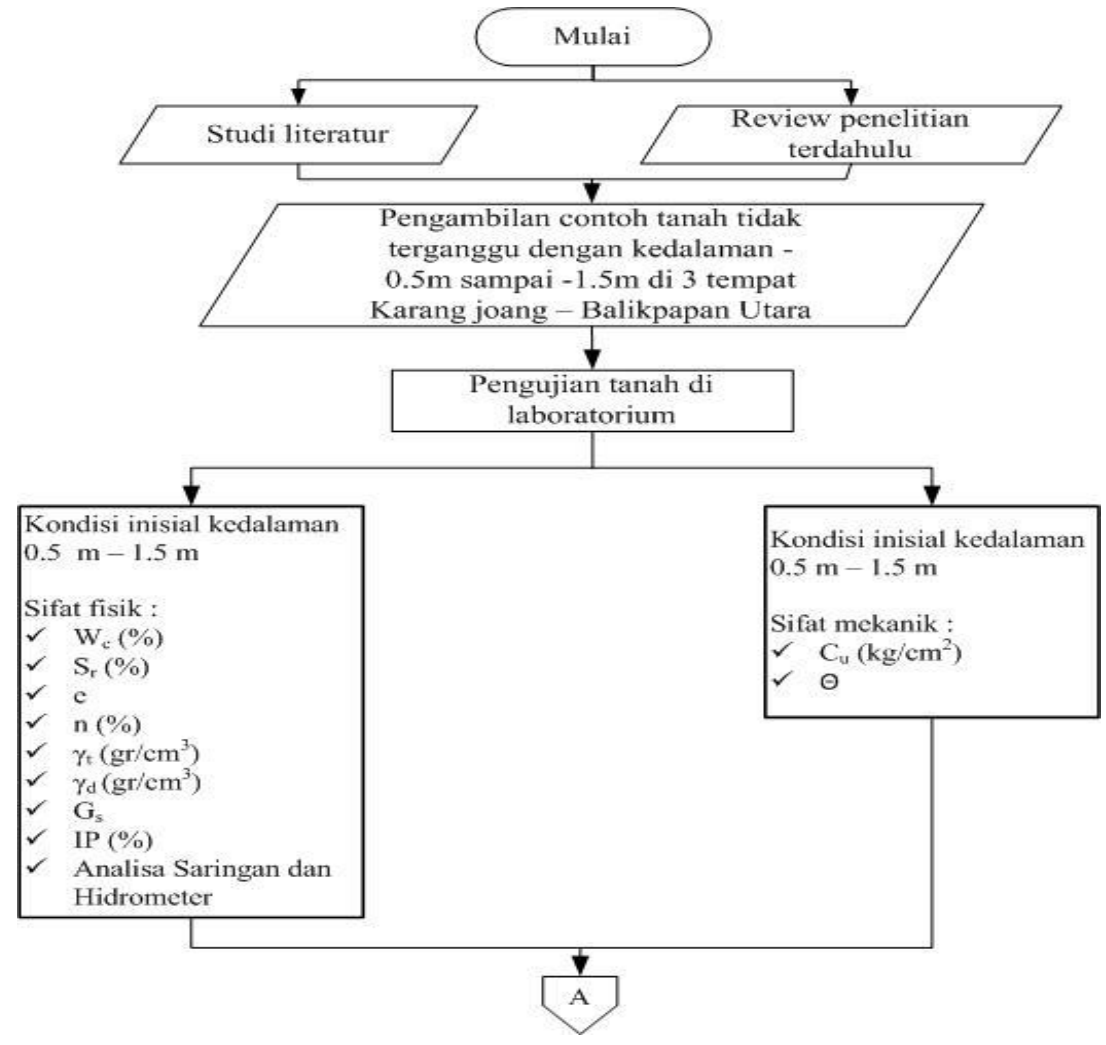




\subsection{Pengujian Sifat Fisik}

Pengujian sifat fisik tanah dilakukan dengan menggunakan alat uji standar di Laboratorium Teknik Sipil Institut Teknologi Kalimantan. Pengujian sifat fisik tanah meliputi:

\subsubsection{Uji Kadar Air}

Pengujian kadar air (water content, wc) berdasarkan standar uji ASTM D 2216-71 dan SNI 03-1965-1990 yang bertujuan untuk menentukan berat air terhadap berat butiran tanah asli.

\subsubsection{Uji Specific Grafity}

Specific Gravity, Gs, adalah perbandingan antara Berat Jenis Solid, $\square$ s (dari butiran tanah) dengan Berat Jenis Air (= unit weight of water). Jadi : Gs $=\square \mathrm{s} / \square \mathrm{w}$. Pengujian berat jenis (specific gravity) dilakukan dengan menggunakan standar uji ASTM D 854-58 dan SNI 03-1964-1990. Nilai specific gravity (Gs) yang diperoleh akan membantu dalam menentukan jenis tanah yang diuji.

\subsection{Pengujian Sifat Mekanik Tanah}

Pengujian sifat mekanik tanah dilakukan dengan menggunakan alat uji standar di laboratorium mekanika tanah Politeknik Negeri Balikpapan. Pengujian sifat mekanik tanah meliputi :

\subsection{1. $\quad$ Uji Geser Langsung (direct-shear)}

Pengujian geser langsung (direct-shear) dilakukan untuk mendapatkan harga kohesi tanah (c) serta mendapatkan sudut geser dalam tanah $(\varphi)$, yang mana kohesi adalah gaya tarik menarik antara molekul yang sama jenisnya. Gaya ini menyebabkan antara zat yang satu dengan yang lain tidak dapat menempel karena molekulnya saling tolak menolak. Pengujian ini dilakukan dengan menggunakan standar uji ASTM D-3080-72 dan AASHTO T-2376-72. 


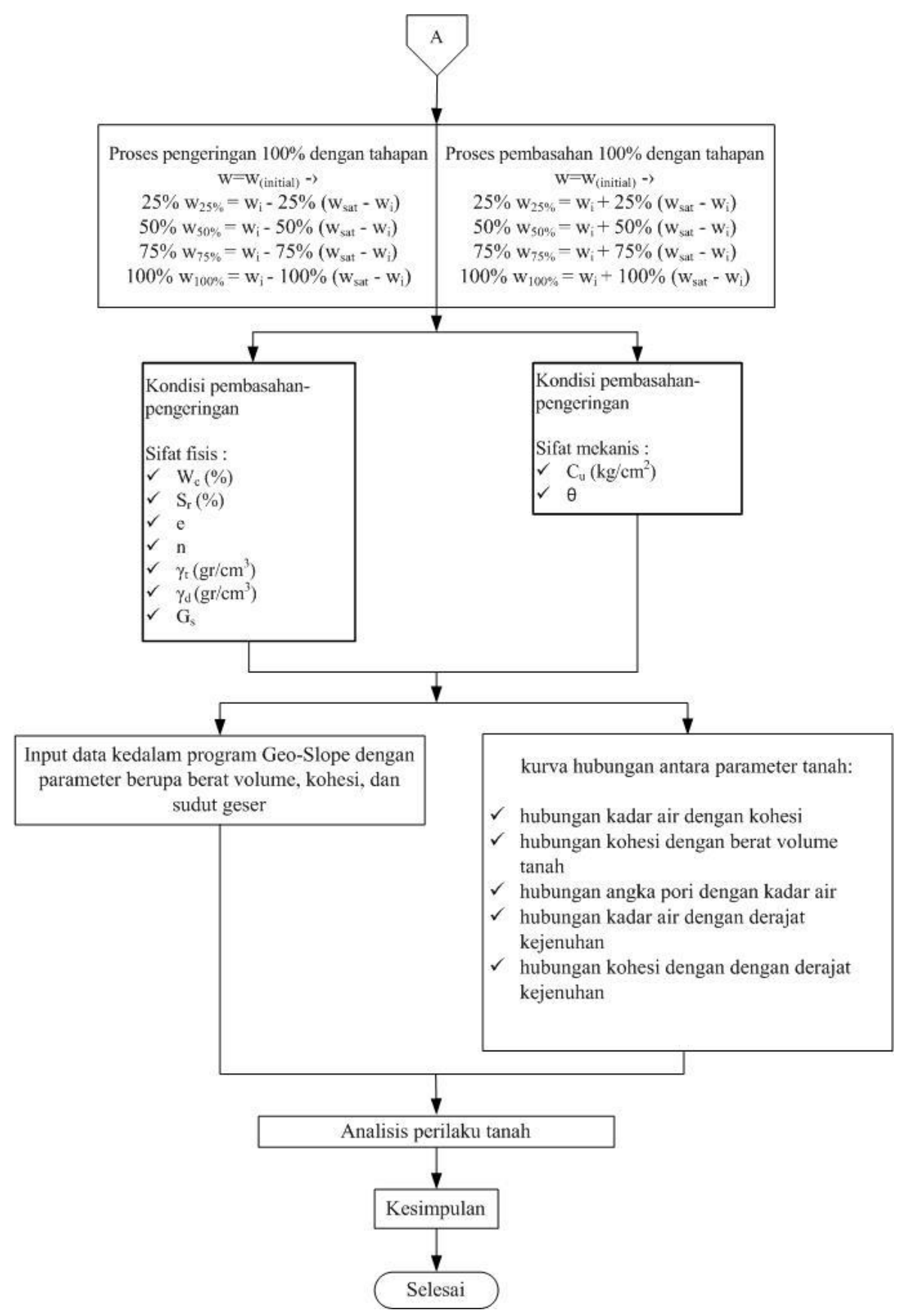

Gambar 3. Lanjutan Bagan Alir Penelitian

\section{HASIL DAN PEMBAHASAN}

Hasil pengujian karakteristik fisik dan mekanis kondisi awal pada 3 lokasi tanah residual yaitu kampus ITK, PLTU Kaltim Kariangau, dan Perumahan joang indah (PJI) Balikpapan Utara; dimana sampel tanah diambil pada kedalaman 0,5- 1,5 m sebagaimana terlihat pada Tabel 3 sampai Tabel 5. Parameter-parameter tanah hasil pengujian meliputi parameter fisik, dan mekanik tanah serta pengaruh pembasahan terhadap perubahan parameter fisik, dan mekanik tanah.

4.1. Pengujian Sifat Fisik dan Mekanik kondisi Awal

1. Uji Gravimetri dan volumetri

Hasil pengujian gravimetri dan volumetri ketiga tanah residual sebagaimana terlihat pada Tabel 4 berikut.

Tabel 4. Hasil Uji Gravimetri dan Volumetri kondisi inisial 


\begin{tabular}{lcccccccccc}
\hline \multirow{2}{*}{ Jenis Pengujian } & \multicolumn{3}{c}{ Kedalaman $(\mathrm{m})$} & \multicolumn{3}{c}{ Kedalaman $(\mathrm{m})$} & \multicolumn{3}{c}{ Kedalaman $(\mathrm{m})$} \\
\cline { 2 - 10 } & \multicolumn{3}{c}{ ITK } & & \multicolumn{3}{c}{ PLTU } & \multicolumn{4}{c}{ PJI } \\
\hline \multicolumn{1}{c}{ Gravimetri dan Volumetri } & 0,5 & 1 & 1,5 & 0,5 & 1 & 1,5 & 0,5 & 1 & 1,5 \\
\hline 1. Specifik Graviti & 2,41 & 2,43 & 2,42 & 2,55 & 2,55 & 2,56 & 2,55 & 2,53 & 2,52 \\
2. Kadar Air, $(\mathrm{w})$ & $(\%)$ & 52,08 & 51,61 & 54,20 & 44,99 & 42,99 & 41,09 & 58,80 & 59,07 & 56,31 \\
3. Berat Volume Tanah, $\gamma_{\mathrm{t}}\left(\mathrm{gr} / \mathrm{cm}^{3}\right)$ & 1,51 & 1,54 & 1,52 & 1,61 & 1,61 & 1,63 & 1,48 & 1,47 & 1,51 \\
4. Berat Volume Kering, $\gamma_{\mathrm{d}}\left(\mathrm{gr} / \mathrm{cm}^{3}\right)$ & 0,99 & 1,02 & 0,99 & 1,11 & 1,13 & 1,16 & 0,93 & 0,93 & 0,96 \\
5. Angka Pori, e & 1,43 & 1,38 & 1,45 & 1,30 & 1,26 & 1,22 & 1,73 & 1,73 & 1,62 \\
6. Derajat Kejenuhan, $\left.\mathrm{S}_{\mathrm{r}}\right)(\%)$ & 87,87 & 90,48 & 90,58 & 88,59 & 86,67 & 86,54 & 86,26 & 86,40 & 87,81 \\
\hline
\end{tabular}

(Sumber : Hasil Penelitian)

2. Nilai Uji Atterberg Limit

Pengujian batas atterberg meliputi batas cair, batas plastis dan indeks plastis. Hasil pengujian selengkapnya dapat dilihat pada Tabel 5 sebagai berikut:

Tabel 5. Nilai Atterberg limit kondisi inisial

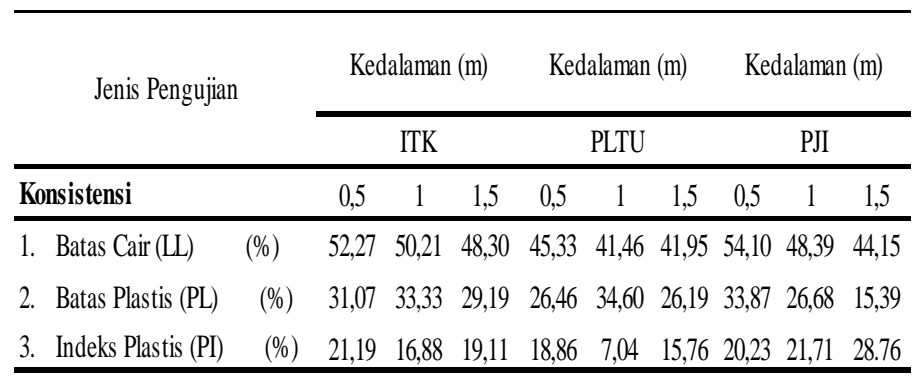

(Sumber : Hasil Penelitian)

Hasil pengujian sifat fisik menunjukkan tanah residual mempunyai nilai sfesifik gravity yang lebih kecil di bandingkan tanah residual PLTU Kariangau dan PJI Balikpapan Utara. Untuk pengujian berat volume, tanah residual PJI mempunyai nilai terendah apabila di bandingkan kedua tanah residual, hasil ini sejalan dengan nilai angka pori tanah resdual PJI yang tertinggi. Hasil perhitungan aktivitas dengan mengunakan nilai indeks plastis pada kedalaman 0,5 meter menunjukkan tanah residual ITK mempunyai nilai $\mathrm{A}=0,409$; tanah residual PLTU mempunyai nilai $\mathrm{A}=0,296$; dan tanah residual PJI mempunyai nilai $\mathrm{A}=0,373$; hasil pengujian menunjukkan ketiga tanah residual ITK, PLTU, dan PJI mempunyai potensi pengembangan sedang.

\subsection{Hasil Pengujian Sifat Fisik dan Mekanik akibat Siklus Pembasahan dan Pengeringan}

Hasil pengujian perubahan kadar air, yang di modelkan dengan penambahan dan pengurangan kadar air sebagaimana terlihat pada Gambar 4.

- Hubungan Kadar Air dengan Kohesi

Gambar 4A adalah hubungan antara kadar air $\left(\mathrm{w}_{\mathrm{c}}\right)$ dengan nilai kohesi $(\mathrm{c})$ pada tanah residual ITK, PLTU Kariangau, dan PJI. Hasil pengujian menunjukkan pembasahan menyebabkan peningkatan nilai kadar air (wc) yang diikuti dengan nilai kohesi tanah menurun. Sebaliknya pada saat pengeringan kadar air mengalamai penurunan dan kohesi mengalami peningkatan.

\section{- Hubungan Berat Volume dan Kohesi}

Gambar 4B menunjukkan perubahan kohesi (c) terhadap perubahan berat volume tanah selama proses pengeringanpembasahan pada tanah residual ITK, PLTU Kariangau, dan PJI. Perubahan kadar air berpengaruh terhadap kohesi (c) dan berat volume $(\gamma)$ tanah, saat pembasahan, semakin besar berat volume tanah maka kohesi mengalami penurunan. Sebaliknya proses pengeringan berat volume tanah mengecil kohesi meningkat. 

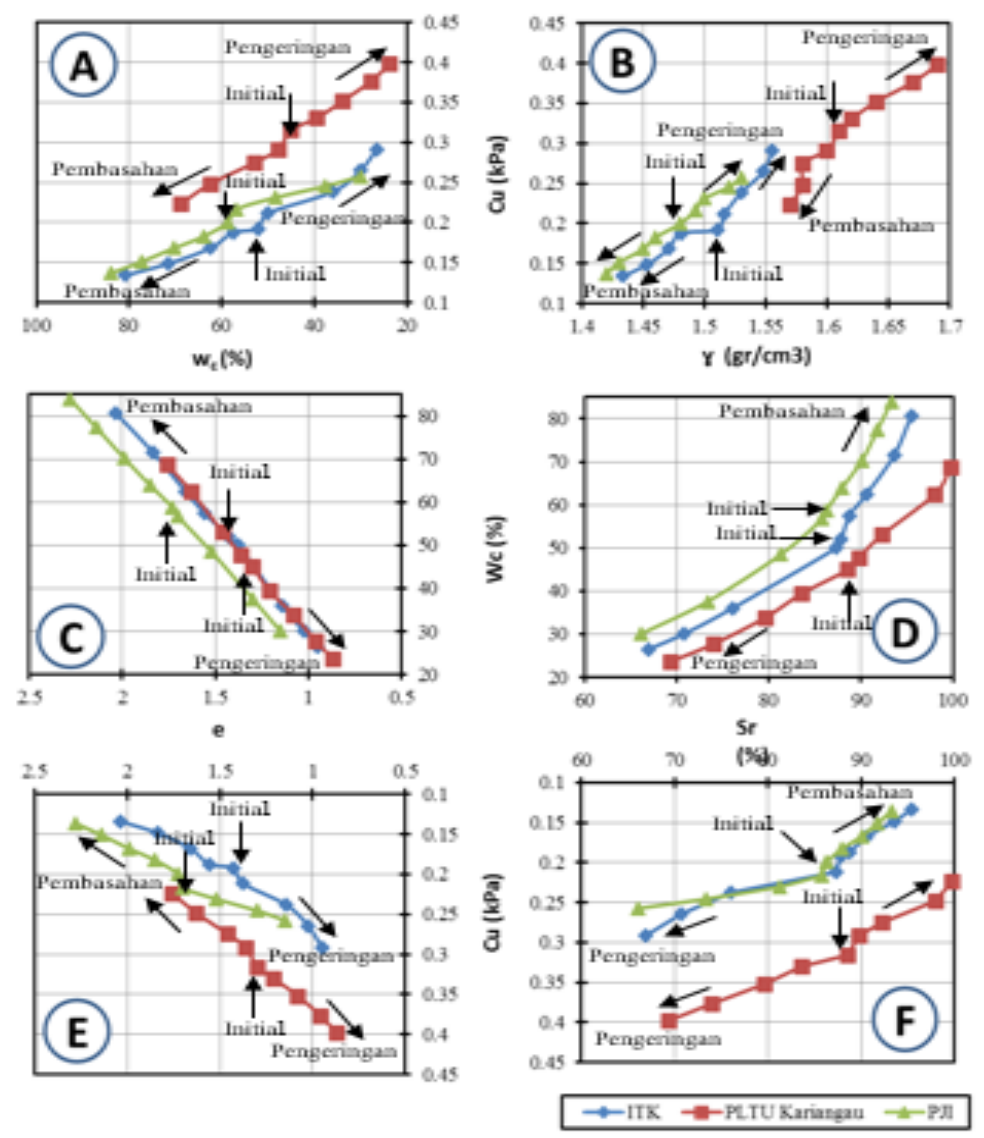

Gambar 4. Kurva hubungan antara kadar air (w), angka pori (e), derajat kejenuhan ( $\mathrm{Sr})$, berat volum $(\gamma)$, dan kohesi (Cu). Pada kedalaman $0.5 \mathrm{~m}$ akibat proses pengeringan-pembasahan pada ketiga benda uji tanah residual.

\section{- Hubungan Angka Pori dengan Kadar Air}

Gambar 4C kurva hubungan antara perubahan angka pori (e) terhadap kadar air (w) dari benda uji tanah residual ITK, PLTU Kariangau, dan PJI. Secara umum ketiga tanah residual mempunyai pola yang sama saat pengeringan angka pori mengecil, sedangkan saat mengalami pembasahan angka pori membesar.

- Hubungan Kohesi dengan Angka Pori

Gambar 4E menunjukkan hubungan antara kohesi (c) dengan angka pori akibat perubahan kadar air pada tanah residual PLTU, ITK, dan PJI. Saat pembasahaan semakin besar angka pori maka kohesi mengalami penurunan. Sedangkan selama proses pengeringan angka pori mengecil akan tetapi kohesi meningkat.

- Hubungan Kohesi dengan Derajat Kejenuhan

Gambar 4F grafik hubungan antara kohesi $(\mathrm{C})$ dengan derajat kejenuhan $\left(\mathrm{S}_{\mathrm{r}}\right)$ akibat pembasahan peengeringan pada tanah residual ITK, PLTU Kariangau, dan PJI. Proses pembasahan yang menyebabkan semakin jenuh suatu tanah maka semakin rendah nilai kohesi.

\section{KESIMPULAN}

Berdasarkan hasil analisis data dan pembahasan, maka penelitian ini menghasilkan beberapa kesimpulan sesuai dengan rumusan masalah sebagai berikut:

1. Pada Berdasarkan hasil pengujian sifat fisik dan mekanik tanah residual yaitu kampus ITK, PLTU kariangau, dan PJI adalah sebagai berikut:

- $\quad$ Ketiga tanah residual ITK, PLTU, dan PJI mempunyai potensi pengembangan sedang.

- Tanah residual ITK termasuk dalam golongan MH (elastic silt), tanah residual PLTU termasuk dalam golongan ML (inorganic slit), sedangkan tanah residual PJI termasuk dalam golongan $\mathrm{CH}$ (fat clay).

- Tanah residual PLTU yang mempunyai kadar lempung tertinggi dan kohesi tertinggi.

2. Perubahan kadar air mempengaruhi kohesi pada ketiga tanah residual, kondisi pembasahan menunjukan nilai kadar air (wc) meningkat diikuti dengan nilai kohesi tanah menurun. Sebaliknya pada saat pengeringan kohesi mengalami peningkatan.

3. Perubahan kadar air berpengaruh terhadap kohesi (c) dan berat volume $(\gamma)$ tanah, saat pembasahan, semakin besar berat volume tanah dan kohesi mengalami penurunan. Sebaliknya proses pengeringan berat volume tanah mengecil dan kohesi meningkat. 
4. Perubahan kadar air mempengaruhi angka pori (e), secara umum ketiga tanah residual mempunyai pola yang sama saat pengeringan angka pori mengecil, sedangkan saat mengalami pembasahan angka pori membesar.

\section{DAFTAR PUSTAKA}

[1] M. Muntaha, "Perilaku Parameter Dinamik (shear modulus) Tanah Residual Akibat Siklus PembasahanPengeringan," Institut Teknologi Sepuluh Nopember, 2012.

[2] B. M. Das, Advanced Soil Mechanics, 2nd ed. 1997.

[3] H. Fredlund, D.G. and Rahardjo, Soil Mechanics for Unsaturated Soils. Rotterdam: Balkema, 1993. 